\title{
Pupils' Motivation and Perceptions on ESL Lessons through Online Quiz-Games
}

\author{
Mohd Shakir Azfar Abdul Halim ${ }^{1}$ \\ Harwati Hashim ${ }^{2 \rtimes}$ (iD \\ Melor Md Yunus ${ }^{3}$ (iD
}

'Sekolah Kebangsaan Ampangan, Seremban, Negeri Sembilan, Malaysia; Faculty of Education, Universiti Kebangsaan Malaysia, Malaysia.

Email:shakirazfar@yahoo.com

${ }^{2, s}$ Faculty of Education, Universiti Kebangsaan Malaysia, Malaysia.

Email:harwati@ukm.edu.my

${ }^{s}$ Email:melor@ukm.edu.my

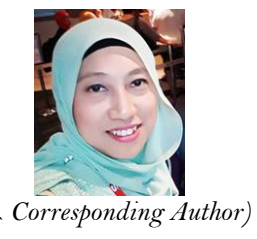

( Corresponding Author

\section{Abstract}

Some scholars believe that the English proficiency and literacy level among the pupils in this country is deteriorating alarmingly and to overcome this issue, many measures have been taken by the government. Research showed that this issue could be caused by lack of motivation among learners to use English in their lives. This study examined pupils' motivation and perceptions of ESL lessons through online quiz-games namely Kahoot! and Quizizz. There were 60 primary school learners involved in this study. Data were collected using a survey questionnaire, and were analyzed and discussed quantitatively in descriptive analysis. The findings revealed that these learners had an elevated motivation and positive perceptions on the inculcation of online quizgames in English lessons. The positive responses shown by the pupils have reflected their positive motivation, perceptions and acceptance towards learning English with the integration of online quiz-games like Kahoot! and Quizizz. This is because the elements of fun, enjoyment and competition in games can make students more motivated and interested in learning English.

Keywords: Online quiz-games, ESL lessons, Motivation, Perception, Technology-enhanced Language Learning, Gamified-learning.

Citation | Mohd Shakir Azfar Abdul Halim; Harwati Hashim; Melor Md Yunus (2020). Pupils' Motivation and Perceptions on ESL Lessons through Online Quiz-Games. Journal of Education and e-Learning Research, 7(3): 229-234.

History:

Received: 5 May 2020

Received: 5 May 2020
Revised: 15 June 2020

Accepted: 17 July 2020

Published: 27 July 2020

Licensed: This work is licensed under a Creative Commons

Attribution 3.0 License (cc) E

Publisher: Asian Online Journal Publishing Group

\begin{abstract}
Acknowledgement: All authors contributed to the conception and design of the study.

Funding: This research is funded by Universiti Kebangsaan Malaysia (UKM) under the research grant no. GG-2019-077 and GGPM-2019-037.

Competing Interests: The authors declare that they have no conflict of

interests.
Transparency: The authors confirm that the manuscript is an honest, accurate, and transparent account of the study was reported; that no vital features of the study have been omitted; and that any discrepancies from the study as planned have been explained.

Ethical: This study follows all ethical practices during writing.
\end{abstract}

\section{Contents}

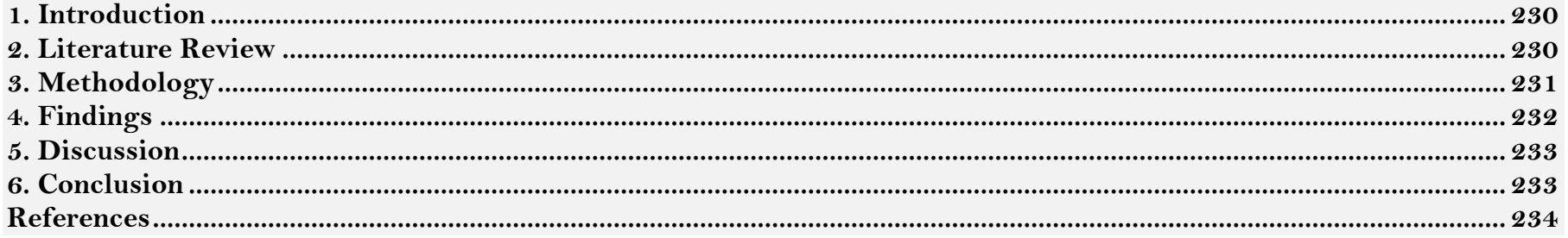




\section{Contribution of this paper to the literature}

This study contributes to the existing literature by examining pupils' motivation and perceptions on the implementation of English as a Second Language (ESL) lessons through online quiz-games namely Kahoot! and Quizizz.

\section{Introduction}

Over the past few years, English has been regarded as a quality for development as well as to obtain knowledge. As stated in Jantmary and Melor (2014) English is referred to as a link language in countries like Kenya and Nigeria, an associate official language in India, an additional language in Ghana, a bridge language in Singapore, a coordinate language in the Philippines and a strong second language in Malaysia. Therefore, it is essential for the current learners, not just in Malaysia, but also in other countries to master this language since English has become a lingua franca in many fields and in many countries.

Some researchers opine that to ensure learners excel in their English learning, teachers have to motivate them to learn in the first place. Wang (2008) and Rafiq, Hashim, Yunus, and Norman (2020) also agreed that extrinsic motivation that is given to students will then determine the intrinsic motivation for them to learn a second language. Thus, a high level of motivation could provide a better learning process among students. To suit Malaysian children's learning styles, songs, rhymes and games could be some tools with high effectiveness to aid children with their second or foreign language acquisition.

Jemima, Melor, and Jamaluddin (2017) stated that the significance of motivation in improving second language is indisputable. They opined that when discussing on the aspects that affect learners' levels of success in second language acquisition, most people would mention motivation as one of the factors. It is believed that one of the effective ways to boost learners' motivation in English lessons is through the use of games also known as "gamification" (Govindasamy, Yunus, \& Hashim, 2019; Pazilah, Hashim, \& Yunus, 2019; Rafiq., Pazilah, Tong, Yunus, \& Hashim, 2020; Yunus, Hashim, Hashim, Sabri, \& Nazeri, 2019). The concept of gamification in education is quite alien, and according to Werbach and Hunter (2012) as cited in Figueroa-Flores (2015) and Ong, Chan, Cho, and Koh (2013) gamification is the integration of the elements of games or game design techniques in non-game contexts. Figueroa-Flores (2015) added that generally, any project, activity, assignment and process or theoretical context can be "gamified". The main goals focus on elevating the learners' participation in the classroom and increase their motivation by integrating game elements and techniques, like leader boards and immediate feedback.

Hence, the researcher chose to incorporate online quiz-games or online game-based learning platforms in his English lessons, and then decided to use Kahoot! and Quizizz in teaching English. These two online quiz-games are stimulating platforms whereby learners can play them online and can compete with other classmates. They are fun game-based learning platforms in which quizzes, survey questionnaires and online discussions could be used in English classrooms. The classroom instructor can also create his/her own quizzes using targeted language, and can play them online with the learners whereby the questions will be projected through the LCD projector, and pupils have to choose and click their answers on their devices or PCs.

Since the concept of gamification can still be assumed to be in its embryonic stage, there is a scarcity of research papers and studies about it. In addition, there have also been few studies that focus on the use of gamification in English learning among primary school pupils. Thus, the researcher believed that there was a need for this study to be conducted. This research focused on not just the primary school pupils, but also the use of gamification, in learning English. Apart from that, through this study, it is hoped that the use of online quiz-games in English lessons could be effectively executed by the teachers for the benefits of the ESL learners.

\section{Literature Review}

Educators and scholars have recognized the significance of motivation in the learning process (Hashim, Yunus, \& Hashim, 2019). Iaremenko (2017) mentioned that motivation is accorded as one of the most powerful catalysts in ESL learning too. There are two types of human motivation namely intrinsic and extrinsic motivations. Iaremenko (2017) also mentioned that intrinsic motivation is long-lasting and self-sustaining, and it is personally driven by enjoyment, positive feelings, or interest. On the other hand, extrinsic motivation is driven by external factors such as rewards, praise and prizes.

The sheer presence of technological tools like online quiz-games and web based learning in teaching and learning process has allowed a whole new world of exploration into the matter of teaching efficacy (Yadollahi \& Rahimi, 2011). Hence, teachers must think carefully which games to be used for a particular lesson, when to use them, how to link them up with the syllabus provided or more explicitly, how different games could provide positive effects to pupils in their learning (Williyam, Melor, \& Azlina, 2016).

\subsection{The Use of Technology and Games in Education}

In the 21 st century, we are living in a digital world in which children can master the use of computers and digital gadgets starting at a young age. Thus, it is not startling to see that nowadays, most language teachers in many countries including Malaysia are using and incorporating digital games in second and foreign language teaching processes particularly for children. According to Aghlara and Tamjid (2011) the use of computer-assisted instruction (CAI) and multimedia in education have meaningfully influenced the learning and cognitive processes of our children. Findings from numerous studies show that a suitable and apt designed CAI programs elevate learners' performances in learning science, mathematics, and literacy.

There was also a study conducted in the country of Turkey by Turgut and İrgin (2009) that investigated language learning of young language learners through computer games. This qualitative research studied the experiences of language learning of young learners while playing computer games in cyber cafes. The authors gathered the data through observations and semi-structured interviews and analyzed them through phenomenological data analysis steps. The results showed that when the participants played online games, it would enhance and improve their language learning, especially in vocabulary learning. 
De Haan (2011) has studied the English teaching and learning process via digital game projects which were game design and game magazine creation. The two extracurricular projects were based on constructionist learning and media literacy theories and practices. The goals of the projects were to monitor learners towards a better comprehension of games' formal features and technologies over their active creation of games and game related media, and to enhance their spoken as well as written English language skills. As a result, learners generally managed to learn and practice a variety of language and technology skills with the design projects. The projects also managed to motivate, challenge, and provide many chances for authentic discussions in the second language among the learners.

Yolageldili and Arikan (2011) conducted research that studied the effectiveness of employing games in grammar lessons for young learners. They, in their study, opined that games can offer language instructors with several benefits when the games are used in classrooms. "One of these advantages is that learners are motivated to learn the language when they are in a game.” (p. 2) Therefore, it is crucial that educators must not view games as time fillers or tools designed for fun per se but incorporate those games into their second or foreign language teaching processes.

\subsection{Motivation and Perceptions in English Learning from the Perspective of Gamification in Education}

Yunus., Osman, and Ishak (2011) believed that language learners have a higher tendency in having positive attitude and higher motivation in second language learning when they are offered with environmental factors that are supportive such as parents, teachers and peers. Consequently, since teachers are included as one of the factors, they have the responsibility to provide learners with language lessons that could enrich their positive attitude and motivation towards learning the second language. The significance of motivation in augmenting second language learning is indisputable (Jemima et al., 2017). Williyam et al. (2016) suggested that the utilization of games is effective in drawing students' attention as well as motivation, because playing games provides social interaction with other learners in virtual environments.

It is also believed that using games in language classrooms stimulates positive affective factors such as increased motivation and engagement. Since games involve pupils, even those who are usually quiet will become more active (Rankin, Morrison, McNeal, Gooch, \& Shute, 2009). Williyam et al. (2016) added that games can aid and reassure learners to sustain their interest and work. They are believed to be helpful for teachers to provide useful and meaningful context in their teaching with the element of fun in it. Therefore, the meaning of the second language will be more richly experienced, and better remembered.

Rajendran, Nor, and Melor (2019) also studied pupils' motivation and perceptions towards ESL learning using Quiz Vaganza, a tool to increase pupils' motivation and engagement in an ESL classroom. They stated that the method used succeeded in stimulating pupils to learn English more effectively and interestingly. Based on their study, it was found that pupils' interest towards ESL learning in classroom was significantly increased. Apart from that, they also stated that the use of gamification in education had a positive impact on pupil's motivation as they really enjoyed learning English using games that were inculcated in the lessons.

\subsection{Related Theories}

According to Mayer (2014) there are many theories that were in relation of how games aid the learning process. A prominent theory selected to be discussed in this paper is the reinforcement theory that was developed by E. L. Thorndike. The reinforcement theory suggested that behaviors that are followed by satisfaction are more likely to be repeated in the future under the same circumstances, whereas the behaviors that are accompanied by dissatisfaction are not prone to be repeated in the future. Relating this theory to this study, it means that using games in to foster learning is regarded to be beneficial for learners, as games often utilize the kind of reinforcing feedback (Erkkila, 2017). As an example, if learners manage to score in the game played in a learning process, positive feedback will be given, hence it would make them feel good about themselves, and thus would inculcate positive attitude and high motivation in learning.

The next theory which has majorly driven and influenced this study was Gardner's Motivation Theory in second language acquisition. This theory has been providing a lot of influences in the second language learning field for many years. Gardner (2001) stated that motivation includes three elements which are effort, desire and also positive affection. Gardner. (1985) stated that the role of orientations (integrative and instrumental) or goals is to intrigue motivation and drive it to achieve the goals. Based on this theory, integrative orientation refers to the positive attitude towards the second language society and the needs to get close to the society, or even be a part of it, whereas instrumental orientation refers to learning a second language for pragmatic causes, in example getting a reward or a better job in life (Hsuan-Yau, 2013).

Therefore, based on all these studies, it is believed that the use of online quiz-games in learning English would benefit pupils in terms of ameliorating their attitude, motivation, engagement and perception in learning the second language. In other words, the gamification in education is essential in today's modern classrooms, and if it is established that games can offer intense and significant practice of the second language, it must be viewed as crucial to an educator's teaching repertoire (Wright 1984 cited in Williyam et al. (2016)).

\section{Methodology}

This study employed a quantitative research design that involved 60 pupils from a primary school in a state in Malaysia. The participants, selected through convenient sampling, consisted of those who have intermediate to low levels of proficiency and fluency in English. Most of the pupils in these two classes were not able to speak in English accurately without any guidance; and they seemed indifferent in fully using the language inside and outside the classroom. They were also observed to be very inactive and chose not to talk much in English lessons. Apart from that, they seemed uninterested to converse in English. This research took place over a period of two weeks. Both classes had the English lessons accordingly, and then underwent the online quiz-games in each lesson either in the middle of the lesson as exercises or at the end of it as a recap activity. 
The research instrument that was utilized was a survey questionnaire consisted of fifteen items. The questionnaire items were adapted from Gardner's Attitude and Motivation Test Battery (AMTB) according to the need of this study. Some items were also adapted from Rajendran et al. (2019) who had also adapted them from Gardner's AMTB. The items in the questionnaire were ranged using four-point Likert scale which participants had to tick based on what their responses were towards each item. The survey questionnaire was given to students to answer on the last day of the research period which was the fourteenth day. The items in the questionnaire were also thoroughly explained orally through translation by the researcher for the participants who found it very hard to understand. Then, the results collected from the instrument were analyzed to answer RQ1 and RQ2 with the utilization of frequency counts and percentages were described descriptively.

\section{Findings}

The fifteen items in the survey were intended to examine students' motivation and perceptions towards ESL learning through online quiz-games particularly Kahoot! and Quizizz. The data gathered were tabulated in Table 1 below, and were analyzed descriptively.

Table-1. Pupils' motivation towards learning English using online quiz-games like Kahoot! and Quizizz in frequency counts and

\begin{tabular}{|c|c|c|c|c|c|}
\hline \multicolumn{5}{|c|}{ Section A: Pupils' motivation towards learning English using Kahoot! and Quizizz. } & \multirow[b]{2}{*}{ Strongly Agree } \\
\hline Item & Statements & Strongly Disagree & Disagree & Agree & \\
\hline A1 & $\begin{array}{l}\text { I enjoy learning English using games } \\
\text { like Kahoot! and Quizizz. }\end{array}$ & - & - & $\begin{array}{c}11 \\
(18.3 \%) \\
\end{array}$ & $\begin{array}{c}49 \\
(81.7 \%) \\
\end{array}$ \\
\hline A2 & $\begin{array}{l}\text { I am interested to learn English in } \\
\text { school. }\end{array}$ & - & - & $\begin{array}{c}25 \\
(41.7 \%)\end{array}$ & $\begin{array}{c}35 \\
(58.3 \%)\end{array}$ \\
\hline A3 & $\begin{array}{l}\text { I prefer to spend more time in English } \\
\text { class than other classes. }\end{array}$ & - & $\begin{array}{c}6 \\
(10 \%) \\
\end{array}$ & $\begin{array}{c}31 \\
(51.7 \%)\end{array}$ & $\begin{array}{c}23 \\
(38.3 \%)\end{array}$ \\
\hline A4 & $\begin{array}{l}\text { I think I can improve my English } \\
\text { through games like Kahoot! and } \\
\text { Quizizz. }\end{array}$ & - & $\begin{array}{c}4 \\
(6.7 \%)\end{array}$ & $\begin{array}{c}29 \\
(48.3 \%)\end{array}$ & $\begin{array}{c}27 \\
(45 \%)\end{array}$ \\
\hline A5 & $\begin{array}{l}\text { I feel more confident to use English if } \\
\text { I learn English in a fun way. }\end{array}$ & - & $\begin{array}{c}7 \\
(11.7 \%) \\
\end{array}$ & $\begin{array}{c}23 \\
(38.3 \%)\end{array}$ & $\begin{array}{c}30 \\
(50 \%) \\
\end{array}$ \\
\hline A6 & I think my English class is boring. & - & - & $\begin{array}{c}11 \\
(18.3 \%)\end{array}$ & $\begin{array}{c}49 \\
(81.7 \%)\end{array}$ \\
\hline A7 & $\begin{array}{l}\text { I like to compete with my friends } \\
\text { when playing games like Kahoot! and } \\
\text { Quizizz. }\end{array}$ & - & $\begin{array}{c}9 \\
(15 \%)\end{array}$ & $\begin{array}{c}51 \\
(85 \%)\end{array}$ & - \\
\hline A8 & $\begin{array}{l}\text { I think it is fun to work together with } \\
\text { my friends when learning } \\
\text { English. }\end{array}$ & - & $\begin{array}{c}9 \\
(15 \%)\end{array}$ & $\begin{array}{c}33 \\
(55 \%)\end{array}$ & $\begin{array}{c}18 \\
(30 \%)\end{array}$ \\
\hline
\end{tabular}

Source: Instrument adapted from Gardner's Attitude and Motivation Test Battery (AMTB) and Rajendran et al. (2019).

Based on the Table 1, 49 out of 60 participants or $81.7 \%$ of them strongly agreed with item A1 (I enjoy learning English using games like Kahoot! and Quizizz), whereas the rest of them (18.3\%) agreed with the statement given. None of them answered 'Strongly Disagree' or 'Disagree'.

Then, 35 or $58.3 \%$ of the participants strongly agreed with item A2 (I am interested to learn English in school), whereas 25 or $41.7 \%$ of them selected 'Agree' in the survey given. As with the previous item, none of the participants selected 'Strongly Disagree' or 'Disagree' for this item.

Next, for item A3 (I prefer spend more time in English class than other classes), 31 out of 60 participants or $51.7 \%$ of them agreed with the statement, whereas 23 or $38.3 \%$ of them strongly agreed, and only 6 or $10 \%$ of them disagreed with the statement. No participant selected 'Strongly Disagree' for this item.

29 or $48.3 \%$ of the participants agreed with the statement in item A4 (I think I can improve my English through games like Kahoot! and Quizizz), whereas 27 or $45 \%$ of them strongly agreed, and only 4 or $6.7 \%$ of them disagreed with the statement. As with the previous item, no participant selected 'Strongly Disagree' for this item.

Next, 30 participants or $50 \%$ of them strongly agreed with the statement in item A5 (I feel more confident to use English if I learn English in a fun way), whereas 23 or $38.3 \%$ of them selected 'Agree', and none of them selected 'Strongly Disagree' or 'Disagree' for this item.

For item A6 (I think my English class is boring), out of 60 participants, 49 or $81.7 \%$ of them strongly agreed with the statement given, and 11 or $18.3 \%$ of them agreed with it. None selected either 'Strongly Disagree' or 'Disagree'.

Then, 51 or $85 \%$ of the participants agreed with the statement in item A7 (I like to compete with my friends when playing games like Kahoot! and Quizizz), whereas only 9 or $15 \%$ of them selected 'Disagree' for this item. No participant selected 'Strongly Disagree' and 'Strongly Agree' for this item.

Last but not least, 33 out of 60 participants or $55 \%$ of them agreed with the statement in item A8 (I think it is fun to work together with my friends when learning English), whereas 18 or $30 \%$ of them strongly agreed, and only 9 or $15 \%$ of them disagreed with the statement. None selected 'Strongly Disagree' for this item.

In the next part of this chapter, the frequency counts and percentages of the pupils' perceptions towards ESL learning via online quiz-games like Kahoot! and Quizizz was tabulated in the Table 2. 
Table-2. Pupils' perceptions towards learning English using online quiz-games like Kahoot! and Quizizz in frequency counts and percentages.

\begin{tabular}{|c|c|c|c|c|c|}
\hline \multicolumn{5}{|c|}{ Section B: Pupils' perceptions towards learning English using Kahoot! and Quizizz. } & \multirow[b]{2}{*}{ Strongly Agree } \\
\hline Item & Statements & Strongly Disagree & Disagree & Agree & \\
\hline $\mathrm{B} 1$ & $\begin{array}{l}\text { Learning English using Kahoot! and Quizizz } \\
\text { increases my interest to learn. }\end{array}$ & - & - & $\begin{array}{c}9 \\
(15 \%) \\
\end{array}$ & $\begin{array}{c}51 \\
(85 \%) \\
\end{array}$ \\
\hline $\mathrm{B} 2$ & $\begin{array}{l}\text { Using online quiz-games like Kahoot! and } \\
\text { Quizizz is helpful to improve my English. }\end{array}$ & - & $\begin{array}{c}3 \\
(5 \%) \\
\end{array}$ & $\begin{array}{c}20 \\
(33.3 \%) \\
\end{array}$ & $\begin{array}{c}37 \\
(61.7 \%) \\
\end{array}$ \\
\hline B3 & $\begin{array}{l}\text { Learning English through games enables me } \\
\text { to communicate more with my teacher and } \\
\text { friends. }\end{array}$ & - & - & $\begin{array}{c}39 \\
(65 \%)\end{array}$ & $\begin{array}{c}21 \\
(35 \%)\end{array}$ \\
\hline $\mathrm{B} 4$ & $\begin{array}{l}\text { Using online games to learn English is a fun } \\
\text { method. }\end{array}$ & - & - & - & $\begin{array}{c}60 \\
(100 \%) \\
\end{array}$ \\
\hline B5 & $\begin{array}{l}\text { Using Kahoot! and Quizizz makes me want to } \\
\text { study English more to be good in it. }\end{array}$ & - & $\begin{array}{c}3 \\
(5 \%)\end{array}$ & $\begin{array}{c}12 \\
(20 \%)\end{array}$ & $\begin{array}{c}45 \\
(75 \%)\end{array}$ \\
\hline B6 & $\begin{array}{l}\text { Learning English through Kahoot! and } \\
\text { Quizizz increases my attention in class. }\end{array}$ & - & $\begin{array}{c}5 \\
(8.3 \%) \\
\end{array}$ & $\begin{array}{c}30 \\
(50 \%) \\
\end{array}$ & $\begin{array}{c}25 \\
(41.7 \%) \\
\end{array}$ \\
\hline B7 & $\begin{array}{l}\text { Using games to learn English makes me feel } \\
\text { less nervous in the class. }\end{array}$ & - & - & $\begin{array}{c}51 \\
(85 \%) \\
\end{array}$ & $\begin{array}{c}9 \\
(15 \%) \\
\end{array}$ \\
\hline
\end{tabular}

Source: Instrument adapted from Gardner's Attitude and Motivation Test Battery (AMTB) and Rajendran et al. (2019).

Based on Table 2, it was found that out of 60 students, 51 or $85 \%$ of them strongly agreed with the statement in item B1 (Learning English using Kahoot! and Quizizz increases my interest to learn), whereas 9 or $15 \%$ of them selected 'Agree' in the questionnaire for this item. For item B2 (Using online quiz-games like Kahoot! and Quizizz is helpful to improve my English), it was found that 37 pupils or $61.7 \%$ of them strongly agreed with the statement given, whereas 20 or $33.3 \%$ of the participants agreed, and only 3 or $5 \%$ of them disagreed with it. None of them selected 'Strongly Disagree' for this item.

Then, 39 or $65 \%$ of the students selected 'Agree' for the statement in item B3 (Learning English through games enables me to communicate more with my teacher and friends), whereas the rest or $35 \%$ of them selected 'Strongly Agree', and none of them selected 'Strongly Disagree' and 'Disagree'. For item B4 (Using online games to learn English is a fun method), all 60 participants (100\%) agreed with the statement provided.

Next, out of 60 participants, 45 or $75 \%$ of them strongly agreed with the statement provided in item B5 (Using Kahoot! and Quizizz makes me want to study English more to be good in it), whereas 12 or $20 \%$ of them selected 'Agree', 3 or 5\% of them selected 'Disagree', and no one selected 'Strongly Disagree' for this item. Half of the participants or 50\% of them selected 'Agreed' or the item B6 (Learning English through Kahoot! and Quizizz increases my attention in class), whereas 25 or $41.7 \%$ of them selected 'Strongly Agree', and only 5 or $8.3 \%$ of them selected 'Disagree'. None of them strongly disagreed with the statement in this item. Last but not least, for item B7 (Using games to learn English makes me feel less nervous in the class), 51 or $85 \%$ of the participants agreed with the statement, whereas 9 or 15\% of them strongly agreed with it, and none of them selected 'Strongly Disagree' or 'Disagree' for this item.

\section{Discussion}

\subsection{Pupils' Level of Motivation in Learning English Through the Use of Online Quiz Games}

The findings in this research suggested that pupils had a higher level of motivation towards learning English using online quiz-games. It was shown that most of the participants selected 'Agree' and 'Strongly Agree' in all the items in the questionnaire. Only a few of them selected 'Disagree' in only a few items. This showed that the students felt motivated and highly interested towards learning English via the incorporation of the online quizgames. The table also showed that most participants felt more confident to use English if they learn the language in a fun way. They were more willing to improve their English, so that they could be better at it through the games. Hence, since they felt more confident during English lessons, they preferred to spend more time to learn English because they did not feel bored after engaging in English lessons assimilated with online quiz-games like Kahoot! and Quizizz. Therefore, it was concluded that the inculcation of online quiz-games in English lessons is able to elevate high motivation among ESL learners to perform better in classroom.

\subsection{Pupils' Perceptions and Expectations towards the Use of Online Quiz-Games in Learning English}

To answer RQ2, Table 2 suggested that pupils had good and positive perceptions towards learning English with the integration of online quiz-games. It was shown that most of them perceived the use of gamification in the ESL learning as helpful to improve their English skills. A lot of them believed that learning English through online quiz-games like Kahoot! and Quizizz was able to increase their interest and communication skills in English. Most of them believed that using games to learn English made them less nervous in their learning process, which made them to be more willing to pay more attention in classroom; and to be more ready to improve themselves in English lessons.

Therefore, it was concluded that ESL learners are more prone towards learning English via online quiz-games like Kahoot! and Quizizz. This also showed that they prefer to learn more by assimilating ICT in their ESL learning process instead of the traditional 'chalk-and-talk' method of learning (Rajendran et al., 2019).

\section{Conclusion}

In conclusion, based on the findings, it is noteworthy to agree that in the context of this research, the integration of online quiz-games could elevate ESL learners' motivation and herald positive perceptions in learning English. This was proven in both research instruments used in this study which were the observations as well as 
the survey questionnaire. The positive responses shown by them have reflected their positive motivation, perceptions as well as acceptance towards learning English with the integration of online quiz-games like Kahoot! and Quizizz. This is because the elements of fun, enjoyment and competition in games can make students more motivated and interested to learn English.

This can be related back to the main theory of this study which was Gardner's Motivation Theory which stated that motivation includes three elements which are effort, desire and also positive affection. As mentioned previously, Gardner. (1985) stated that the role of orientations (integrative and instrumental) or goals is to intrigue motivation and drive it to achieve the goals. Since the online quiz-games used in their ESL lessons manage to intrigue their motivation, it drove them to be more interested and motivated to learn English which in this case, was the goal of this study.

It is hoped that this research and its findings were beneficial to all stakeholders especially teachers. This is because teaching methodology is one of the prominent aspects that teachers need to ponder upon to provide a successful and meaningful teaching and learning process to learners. Hence, although this study was a small-scale study focusing on the opinions of only 60 participants, it could be regarded as a meaningfully vital and essential step in recognizing the classroom instructors' views on a significant issue which is young learners' learning of English via online quiz-games.

\section{References}

Aghlara, L., \& Tamjid, N. H. (2011). The effect of digital games on Iranian children's vocabulary retention in foreign language acquisition. Procedia-Social and Behavioral Sciences, 29, 552-560.Available at: https://doi.org/10.1016/j.sbspro.2011.11.275.

De Haan, J. (2011). Teaching and Learning English through digital game projects. Digital Culture Eं Education, 3(1), 46-55.

Erkkila, M. (2017). Learning English from digital games: Finnish upper secondary school students' perspective on game-enhanced language learning, 2017. Unpublished Master's Thesis, University of Jyvaskyla, Finland.

Figueroa-Flores, J. F. (2015). Using gamification to enhance second language learning. Digital Education Review, 35(1), 15-30.Available at: https://doi.org/10.1344/der.2015.27.32-54.

Gardner, R. C. (2001). Integrative motivation and second language acquisition. In. Dornyei \& Schmidt (Eds.), Motivation and second language acquisition (pp. 119). Hawaii: University of Hawaii Press.

Gardner., R. C. (1985). Social psychology and second language learning: The role of attitudes and motivation. London Edward Arnold.

Govindasamy, P., Yunus, M. M., \& Hashim, H. (2019). Mobile assisted vocabulary learning: Examining the effects on students' vocabulary enhancement. Universal Journal of Educational Research, 7(12A), 85-92.Available at: https://doi.org/10.13189/ujer.2019.071911.

Hashim, H., Yunus, M., \& Hashim, H. (2019). 3-Minutes pitching with flip grid: An antidote of innovation for speaking anxiety. International Journal of Innovative Technology and Exploring Engineering, 8(7), 1798-1801.

Hsuan-Yau, L. T. (2013). The motivation of learners of english as a foreign language revisited. International Education Studies, 6(10), 90-101.

Iaremenko, N. V. (2017). Enhancing English language learners' motivation through online games. Information Technologies and Teaching Aids, $59(3), 126-133$.

Jantmary, T., \& Melor, M. Y. (2014). Status of English in Malaysia. Asian Social Science, 10(14), 254-250.Available at: 10.5539/ass.v10n14p254.

Jemima, T., Melor, M. Y., \& Jamaluddin, B. (2017). Learning English is fun via Kahoot: students' attitude, motivation and perceptions Paper presented at the Proceedings on Seminar on Transdisiplin Education.

Mayer, R. (2014). Computer games for learning. Cambridge: The MIT Press.

Ong, D., Chan, Y. Y., Cho, W. H., \& Koh, T. Y. (2013). Motivation of learning: An assemssment of the practicality and effectiveness of gamification within a tertiary education system in Malaysia. A Proceeding of World Academy of Researchers, Educators, amd Scholars in Business, Social Sciences, Humanities and Education Conference, 1(1), 132-146.Available at: $\underline{\text { http://eprints.sunway.edu.my/id/eprint/185 }}$

Pazilah, F. N., Hashim, H., \& Yunus, M. M. (2019). Benefits of gamification towards different learning styles in language learning. International Journal of Innovation, Creativity and Change, 5(6), 81-89.

Rafiq, K. M., Hashim, H., Yunus, M. M., \& Norman, H. (2020). Using mobile-based online learning course to learn English for the workplace. International Journal of Interactive Mobile Technologies, 14(8), 19-31.

Rafiq., K. M., Pazilah, F. N., Tong, G. Y., Yunus, M. M., \& Hashim, H. (2020). Game on! development and evaluation of computer games for ESL classroom. International Journal of Scientific \& Technology Research, 9(2), 1976-1980.

Rajendran, T., Nor, A. N., \& Melor, M. Y. (2019). Pupils' motivation and perceptions towards learning English using quizvaganza. International Journal of Scientific and Research Publications, 9(1), 1-9.Available at: 10.29322/IJSRP.9.01.2019.p8529.

Rankin, Y. A., Morrison, D., McNeal, M., Gooch, B., \& Shute, M. W. (2009). Time will tell: In-game social interactions that facilitate second language acquisition. Paper presented at the Proceedings of the 4th International Conference on Foundations of Digital Games, FDG 2009.

Turgut, Y., \& İrgin, P. (2009). Young learners' language learning via computer games. Procedia-Social and Behavioral Sciences, 1(1), 760764.Available at: https://doi.org/10.1016/j.sbspro.2009.01.135.

Wang, F. X. (2008). Motivation and English achievement: An exploratory and confirmatory factor analysis of a new measure for Chinese students of English learning. North American Journal of Psychology, 10(3), 633-646.

Werbach, K., \& Hunter, D. (2012). For the win: How game thinking can revolutionize your business. Philadelphia, PA: Wharton Digital Press.

Williyam, A., Melor, M. Y., \& Azlina, A. A. (2016). Students' perception of using games in the teaching of reading skill. Paper presented at the International Conference on Education 2016.

Yadollahi, S., \& Rahimi, M. (2011). ICT use in EFL classes: A focus on EFL techers' characteristics. World of Journal of English Language, 1(2), 17-29.Available at: 10.5430/wjel.v 1n2p17.

Yolageldili, G., \& Arikan, A. (2011). Effectiveness of using games in teaching grammar to young learners. İlköğretim Online, 1O(1), $219-229$.

Yunus, M. M., Hashim, H., Hashim, H. U., Sabri, F. S., \& Nazeri, A. N. (2019). Kahoot!: Engaging and active learning environment in ESL writing classrooms. International Journal of Innovation, Creativity and Change, 5(6), 141-152.

Yunus., M. M., Osman, W. S. W., \& Ishak, N. M. (2011). Motivation and attitudes for learning English among year six students in primary rural school. Procedia-Social and Behavioral Sciences, 15, 2631-2636.Available at: https://doi.org/10.1016/j.sbspro.2011.04.160. 